\title{
CUSTOMER CHURN ANALYSIS WITH BACK-PROPAGATION NEURAL NETWORK: CASE INTERNET SERVICE PROVIDER XYZ
}

\author{
Ali Reza Yudhistira ${ }^{1}$, Febriliyan Samopa ${ }^{2}$ \\ ${ }^{I}$ S.Kom, Master of Technology Management, Sepuluh Nopember Institute of Technology, Surabaya, Indonesia \\ ${ }^{I}$ S.Kom, M.Kom, Master of Technology Management, Sepuluh Nopember Institute of Technology, Surabaya, Indonesia
}

\begin{abstract}
Number of Internet users worldwide is likely to increase exponentially. It is an opportunity for companies that specialize in Internet Service Provider (ISP). An ISP in Surabaya, ISP xyz, their customers do churn each month. Customer churn bring loss in revenue for the company. ISP xyz want to know the prediction when the customer will do churn and the factors that affect customer churn. In this paper, customer churn analysis in Interne service provider company use data mining technique with neural network method, because it produce result better than the others. Neural network combined with back propagation model and sigmoid biner function. Back propagation neural network's superiority is learning process that use weight rating point, if weight is not accurate it will do the learning process again. With that method, it will produce prediction customer churn result accurately. The result from this research is the most significantly effect factor for customer churn are the result of surveyl, survey 2, and survey 3. Back propagation neural network has a accuracy $99.99 \%$ to predict customer churn. For reducing customer churn, strategy planning for CRM division is improving customer experience from the customer.
\end{abstract}

Keywords: Customer Churn, Internet Service provider, Back propagation Neural Network, Customer Experience, and Customer Relationship Management

\section{INTRODUCTION}

$\mathrm{XYZ}$ is a Internet service provider in Surabaya segmented in corporate or office user. Competition in this segmentation really competitive, because a customer bring a profit to the company. If the customer unsubscribe, or it called churn, bring a great loss to the company.

Customer churn is a ISP's customer unsubscribe the service and move to other competitor (Haden, 2005). Customer churn become a main problem in corporate, especially a big company(Richeldi\&Perruci, 2001). ISP XYZ get a customer churn every month and it bring a great loss for company.

Churn management is to predict customer who will do churn. If churn rate already know before they churn, the company will do a specific strategy for them to make they stay loyal to company. Cost to win a customer is big, and make they loyal is a must (McPhillips, 1999).

Richeldi\&Perruci (2002) explained data mining method is one of the solution to minimize churn, because the company predict the customer based on their data and it will show the reason why customer do churn. Hung et al (2006) research churn rate from industry telecommunication's customer in Taiwan, conclude that artificial neural network predict more accurate than decision tree. Artificial neural network solved non-linier problem and has a ability to learn the data. Neural network predict based on similarity.

\subsection{Customer Churn}

Customer churn is a name for defined customer who cut the business relationship with the company (Liaou, 2007). Customer churn management is a concept to identify why customer moved to other competitor and that customer become proactive marketing target as retention (Haddenet al, 2005). Customer churn management focused only on a customer who have potential to do churn. because It takes a big cost to keep customer stay loyal.

Telecommunication industry changes rapidly caused by technology growth. When a customer keep increasing and it reach at the top of business, to acquire a new customer will be difficult and it cost a lot, maintaining customer is main priority.

Customer churn analysis used in many sector, one of them is in telecommunication industry. Customer churn rate in that business sector is really high and it potentially bring a loss for company. Customer churndevided in two types, voluntary and non-voluntary.

Voluntary churn is more difficult to detect, because they do based on their own decision. Non-voluntary churn is customer who stop the service unilatraly, such as they don't pay the bill.

\subsection{Data Mining}

Han \&Kember (2011, p36) explained that data mining is a process to find a pattern and knowledge in big amount of data. Data mining grouped in two category, predictive and descriptive.

Predictive data mining is a process to find a pattern for future based on current data. One of the technique is classification. Predicted variable known as dependent variable, and the other attribute to explain the predicted value known as independent variable. 
Table 1.1 Data Mining Technique

\begin{tabular}{|c|c|c|}
\hline Model & Technique & Application \\
\hline \multirow[t]{3}{*}{ Asociation } & Set theory & \multirow[t]{3}{*}{ Cross Sell } \\
\hline & Statistics & \\
\hline & $\begin{array}{l}\text { Bayessian } \\
\text { Classification }\end{array}$ & \\
\hline \multirow[t]{3}{*}{ Estimation } & Neural Network & \multirow{3}{*}{$\begin{array}{l}\text { Exchange rate } \\
\text { estimation } \\
\text { Stock price } \\
\text { estimation }\end{array}$} \\
\hline & Statistic & \\
\hline & Time Series & \\
\hline \multirow[t]{4}{*}{ Classification } & Decision tree & \multirow{4}{*}{$\begin{array}{l}\text { Market } \\
\text { segmentation }\end{array}$} \\
\hline & Fuzzy & \\
\hline & Neural Network & \\
\hline & $\begin{array}{l}\text { Genetic } \\
\text { Algorithm }\end{array}$ & \\
\hline \multirow[t]{3}{*}{ Prediction } & Regression & \multirow{3}{*}{$\begin{array}{l}\text { Churn prediction } \\
\text { Fraudster } \\
\text { prediction }\end{array}$} \\
\hline & Neural Network & \\
\hline & Decision Tree & \\
\hline \multirow[t]{4}{*}{ Segmentation } & Neural Network & \multirow{4}{*}{$\begin{array}{l}\text { Market } \\
\text { segmentation }\end{array}$} \\
\hline & Statistics & \\
\hline & $\begin{array}{l}\text { Genetic } \\
\text { Algorithm }\end{array}$ & \\
\hline & Decision Tree & \\
\hline
\end{tabular}

Descriptive data mining is process to find the characteristic of data. Purpose for this category are to find correlation, trend, clustering, and anomaly. Explaination of every techniques in data mining shown in table 1.1.

\subsection{Neural Network}

Neural network is a method in artificial intelligence based on human body neural network build by connected nodes. Artificial neural network work like a brain to learn a knowledge. Artificial neural network has three layer, input layer, hidden layer, and output layer.

In general artificial neural network, it has to be trained first. It will learn based on the data, and after it learn it will predict the future data. More data for training and it will produce predicted value more accurate. Artificial neural network have some method, such as :

- Back-propagation is supervised training to change weight every nodes in every iteration in hidden layer.

- Bidirectional Associate Memory (BAM) is a model who have hetero associative memory and use only input layer and output layer.

- Radial Based Function (RBF) is a model has two step in training. First step it use unsupervised training, and last step is bring the training result to output layer linearly.

- Multi-layered Perceptron, is a popular model has more than one layer. Training method are using weight optimization with evolutionary programming.

\section{METHODOLOGY}

In this chapter will discuss the research methods for the customer churn analysis with back-propagation neural network. This paper, requires a relatively complete information data as a material that supports the truth and accuracy of the data.

\subsection{Literature Study}

Literature study is a first method for research. In this step author research studied the related topic and the customer churn theory. Author also observe an existing customer data in ISP XYZ based on factor from earlier research.

\subsection{Collecting Data}

The next process is to obtain the data information needed in order to achieve the research objectives. Interest expressed in hypothetical form a temporary answer to question research. The answer remains to be tested empirically, and for the purpose of data collection is required.

\subsection{Customer Churn Analysis}

The next process is analyze customer churn with backpropagation neural network. The methods divided into 3 steps, creating architecture, training, and testing.

\subsection{Customer Relationship Management Strategy}

The final step is create strategy based on the result of neural network method. CRM division have to create a specific strategy to customer who potentially to churn.

\section{DATA ANALYSIS}

In this chapter will discuss an implementation of methodology explained above.

\subsection{Data Preprocessing}

The data collected from billing data, ticketing complaint, bonus, package, and unsubscriber form. Data was collected by a sample data from 2013 to 2016 . The data must be process first before it takes to next step. The data will do some test such as cleansing data, correlation test, validity and reliability test, and multikolinier test.

\subsection{Customer Churn Analysis}

Artificial neural network needs to create the architecture, and training and testing to make them work. Higher amount if data training will produce higher accuracy rate.

\section{Architecture}

Artificial neural network has three layer, input layer, hidden layer, and output layer. Input layer has 11 nodes based on XYZ's customer data, such as billing, package, subscribe age, complaint with high category, complaint with normal category, complaint with low category, bonus, and four survey result from unsubscribe form. 
For hidden layer's nodes author create with Geomatric Pyramid Rule :

$$
f(x)=\sqrt{n * m}
$$

$n$ for input nodes, and $m$ for output nodes. Activation function need for this method. Customer churn analysis use sigmoid biner activation function, because the result to predict customer churn or not.

\subsection{Training and Testing Neural Network}

Next step is training and testing the neural network. Sample data for training are from 2013 to 2015, and data in 2016 for testing. Result explained at table 2.1 and figure 2.1. Training and testing use statistic software SPSS.

Table 2.1 Case Processing Summary

\begin{tabular}{|ll|r|r|}
\hline & & \multicolumn{1}{|c|}{$N$} & Percent \\
\hline Sample & Training & 830 & $80.5 \%$ \\
& Testing & 201 & $19.5 \%$ \\
Valid & & 1031 & $100.0 \%$ \\
Excluded & 5 & \\
Total & 1036 & \\
\hline
\end{tabular}

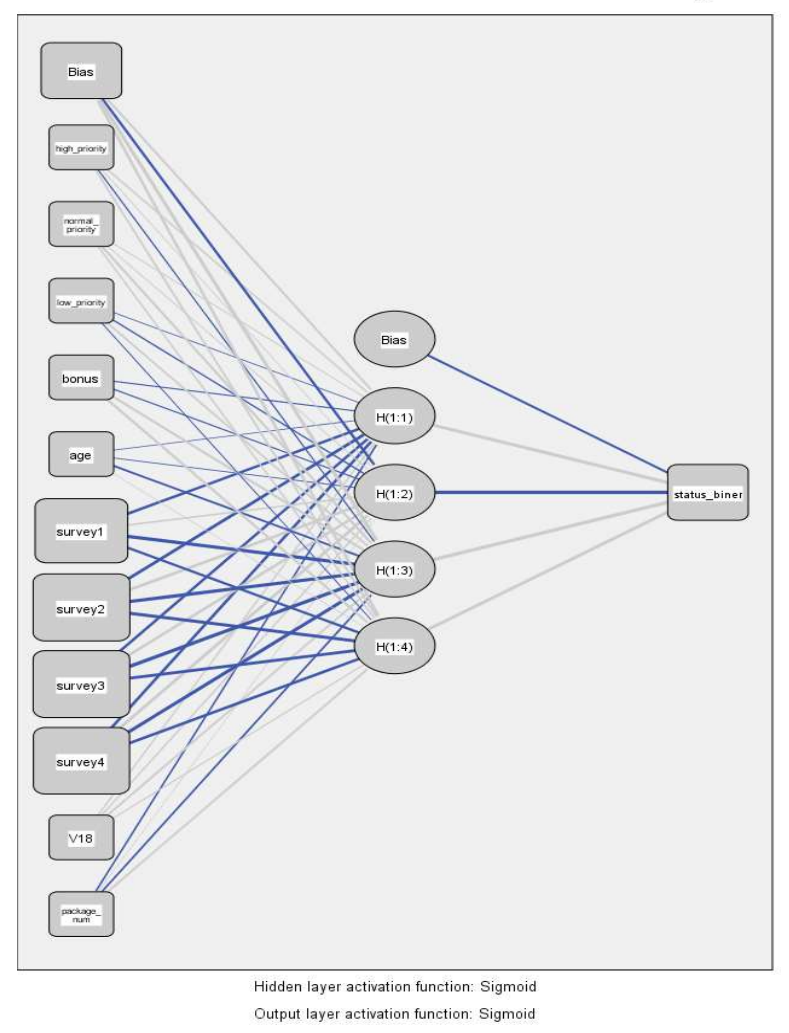

Fig 2.1 Neural Network Result

Table 2.2 Summary

\begin{tabular}{|ll|r|}
\hline Training & Sum of Squares Error & .014 \\
& Relative Error \\
& Stopping Rule Used & \multicolumn{2}{|c|}{$\begin{array}{l}\text { Training error ratio } \\
\text { criterion (001) } \\
\text { achieved }\end{array}$} \\
& Training Time & $000: 00: 00.000$ \\
\hline Testing & Sum of Squares Error & .003 \\
& Relative Error & .000 \\
\hline
\end{tabular}

Table 2.3 Weight Nodes

\begin{tabular}{|c|c|c|c|c|c|c|}
\hline \multirow[b]{3}{*}{ Predictor } & & \multicolumn{5}{|c|}{ Predicted } \\
\hline & & \multicolumn{4}{|c|}{ Hidden Layer 1} & \multirow{2}{*}{$\begin{array}{l}\text { Output Layer } \\
\text { status biner }\end{array}$} \\
\hline & & $\mathrm{H}(1: 1)$ & $\mathrm{H}(1: 2)$ & $H(1 ; 3)$ & $H(1 ; 4)$ & \\
\hline \multirow[t]{12}{*}{ Input Layer } & (Bias) & .521 & -.667 & 1.484 & .795 & \\
\hline & high_priority & .246 & .051 & -.122 & .363 & \\
\hline & normal_priority & .102 & .086 & .581 & .197 & \\
\hline & low_priority & -.040 & -.158 & .409 & -.078 & \\
\hline & bonus & -.107 & -.111 & .588 & .631 & \\
\hline & age & -.032 & -.056 & -.414 & .019 & \\
\hline & survey1 & -.837 & .316 & -2.531 & -.775 & \\
\hline & survey 2 & -.922 & .899 & -2.452 & -1.791 & \\
\hline & survey3 & -.820 & .886 & -2.744 & -1.034 & \\
\hline & survey4 & -.862 & 1.018 & -1.987 & -.886 & \\
\hline & yearly & .171 & .180 & .425 & .124 & \\
\hline & package_num & -.207 & .009 & -.338 & .459 & \\
\hline \multirow[t]{5}{*}{ Hidden Layer 1} & (Bias) & & & & & -.564 \\
\hline & $H(1: 1)$ & & & & & 2.068 \\
\hline & $H(1: 2)$ & & & & & -3.737 \\
\hline & $H(1: 3)$ & & & & & 3.529 \\
\hline & $\mathrm{H}(1: 4)$ & & & & & 1.761 \\
\hline
\end{tabular}

For every node has its weight. It show that how strong that variable affect customer to churn. Weight node explained in table 2.2.

Table 2.3 showed that the result has an accuracy up to $99.99 \%$ in training. The highest weight positive or negative value are showed in row hidden layer $1 \mathrm{H}(1: 2)$ and $\mathrm{H}(1: 3)$. After that in column $\mathrm{H}(1: 3)$ showed that the highest weight are in survey 1 , survey 2 , and survey 3 . It showed that the most important factor for customer churn.

\subsection{Customer Relationship Management Strategy}

At this step, based on previous step explained that the most important factor for customer are survey 1 for what services which make them churn, survey 2 for experience when they use the service, and survey 3 for chance to resubscribe.

CRM have to enhance the customer's experience to make them loyal to the company. According to Pine and Gilmore (1999), experience is a chance to make a profit for the company from customer. Customer experience is an interaction between customer and product to stimulate a few reaction.

Gentile et al (2007) explained, there 4 strategy for customer experience such as :

- Customer vision oriented, change employee vision to served the customer with heart

- Know your customer, know your customer better and it makes them loyal to the company

- Create a emotional bond, relationship not only about work but also a personal life of the customer.

- Real time feedback respond, if customer complain support team or CRM have to respond immediately.

\section{CONCLUSION}

After several steps of methodology could be conclude that :

1. Using back-propagation neural network produce a prediction accuracy up to $99,99 \%$.

2. The most important reason for customer churn are services from company, customer's experiences with the company, and chance to resubscribe 
3. CRM strategy to reduce customer churn is enhance the customer's experience with high level of services

For future research, the data for this research should be from other company to make the result can be used in other telecommunication industries. The data span should be more than 5 year to increase the accuracy.

\section{REFERENCES}

[1] Suharso, W. (2013). Analisis Customer Churn pada Perusahaan Penyedia Layanan Internet Menggunakan Bayesian Belief Network.

[2] Kusumadewi. (2003). Artifical Intellegence (Teknik dan Aplikasinya). yogyakarta: graha ilmu.

[3] Hung, S. D. (2006). Applying Data Mining To Telecom Churn Management, Science Direct, Expert Systems with applications, volume 31, 515-524. .

[4] Hadden, J. T. (2005). Computer Assisted Customer Churn Management: State Of The Art And Future Trends, Science Direct, Computer \& Operations Research, Volume 34, 2902 - 2917.

[5] Richeldi, M. P. (n.d.). Retrieved september 2016, from http://www-ai.cs.uni-

dortmund.de/PublicPublicationFiles/richeldi_perrucci_ 2002b.pdf

[6] Khan, A. J. (2010). Applying Data Mining to Customer Churn Prediction in an Internet Service Provider, International Journal of Computer Applications, Volume 9 - No. 7.

[7] McPhilips, E. (1999). The Structure And Trends Of The ISP Market, University Of Strathclyde, Glasgow And Helett-Packard Laboratories, Bristol .

[8] Liao, T. d. (2007). Recent Advances in Data Mining of Enterprise Data: Algorithms and Applications, World Scientific, Singapore, pp. 1-109.

[9] Gursoy, U. (2010). Customer Churn Analysis In Telecommunication sector, Istanbul University Journal of the School of Business Administration, Vol 39, No 1, 35-49, ISSN: 1303-1732. .

[10] Kriegerl, H. S. (2008). Angle-Based Outlier Detection In High-Dimensional Data, Proc. Of The 14th ACM SIGKDD International 156 Conference On Knowledge Discovery \& Data Mining (KDD’08), 444 - 452, . Las Vegas.

[11] Huang, B. K. (2012). Customer Churn Prediction In Telecommunications, Science Direct, Expert Systems with Application, volume 39, 1414-1425. .

[12] Oseman, K. S. (2010). Data Mining In Churn Analysis Model For Telecommunication Industry, Journal Of Statistical Modeling And Analytics, Vol 1 No. 19-17. . 